\title{
Theoretical and experimental substantiation of the system of local removal of harmful substances during the combustion of candles in the worship hall of Orthodox churches and cathedrals
}

\author{
Alexander Eremkin ${ }^{1}$, and Inna Ponomareva ${ }^{2}$ \\ ${ }^{1}$ Penza State University of architecture and construction, Penza, Russia \\ ${ }^{2}$ Penza State University, Penza, Russia
}

\begin{abstract}
The analysis of the features of Orthodox churches, temples and cathedrals, elements of the design of the halls of worship, and their preservation. The types of hazards generated during the burning of candles and the parishioners and staff present are systematized. Thermal imaging surveys of convective flows formed during candle combustion were carried out. A technique for conducting experiments and a diagram of an experimental setup for measuring the temperature and air velocity in a convective jet have been developed. The diagram of the convective flow structure is presented, which consists of individual jets from each candle. The results of the study have been obtained, which make it possible to determine the area of stable convective flow and the place of installation of the exhaust hood above the candlestick, as well as the distance between the burning candles and the edge of the bottom of the umbrella. A local mechanical exhaust ventilation system with umbrellas has been developed to trap and remove harmful substances from the worship hall and provide comfortable conditions for parishioners and preserve the decoration elements of the halls. The characteristics and conditions for the efficient operation of the hoods in the local exhaust ventilation system and the factors influencing their operation are given.
\end{abstract}

An innovative system of local removal of harmful substances is proposed in this article on the basis of the conducted studies of the convective flow when burning candles over a candlestick in the worship hall of the Church of the Holy First Apostles Peter and Paul in Penza. Currently, in the regions of Russia, a large-scale reconstruction of the destroyed ones, the reconstruction of existing ones, the construction of new Orthodox churches, temples and cathedrals are being carried out (Fig. 1). 
a)

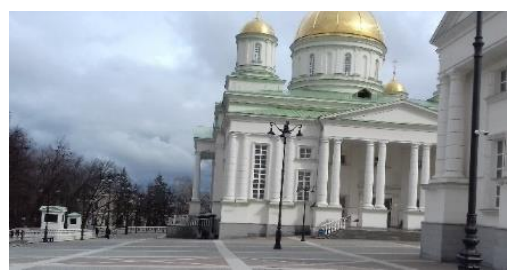

b)

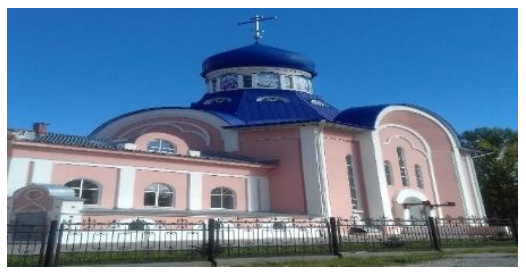

Fig. 1. General view of one of the built cathedrals in Penza: a) Spassky Cathedral; b) the Temple of the Holy Apostles Peter and Paul

A feature of Orthodox churches, cathedrals and temples is the presence in the worship hall of works of architecture, artistic paintings, icons, frescoes, decoration of the iconostasis, icon case and others, which have historical and artistic value. To ensure the safety of the design elements, high requirements are imposed on the parameters of the artificial internal microclimate tv, $\varphi v, \mathrm{Vv}$ and air purity. At the same time, it is necessary to provide comfortable conditions for parishioners and service personnel in the worship hall, which is a difficult task due to the harmful emissions from people, heat, moisture, carbon dioxide, and especially during the combustion of candles - soot, soot, moisture, carbon dioxide, heat [14].

It has been established that several dozen candlesticks and hundreds of burning candles are installed in the halls of worship during the service period (Fig. 2). Burning candles on candlesticks are also installed on ordinary days for parishioners when visiting cathedrals. Based on the research and analysis of the movement of ventilation air flows and the natural movement of air inside the worship hall, it was found that emitting soot and soot, due to incomplete combustion of paraffin from candles, settle on the inner surfaces of the worship hall, paintings, icons, paintings and on the clothes of parishioners. As a result, the decoration of the hall over the years acquires a smoky, unsightly appearance. Other emitted hazards: heat, moisture, carbon dioxide, negatively affect the well-being of parishioners and the decoration of the hall [5].
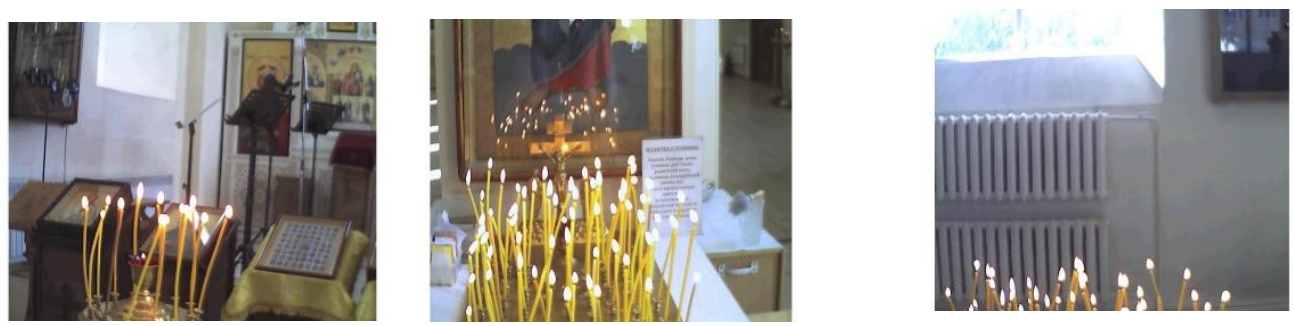

Fig. 2. Demonstration shot of burning candles on different candlesticks in the worship hall of the Church of the Holy Primate Apostles Peter and Paul

To confirm the conclusions made, experimental studies of the emission of soot and soot when burning candles were carried out. At the same time, a specially designed in the creative workshop of D.A. Trofimov's "Tsargrad" stand (Fig. 3). 
a)

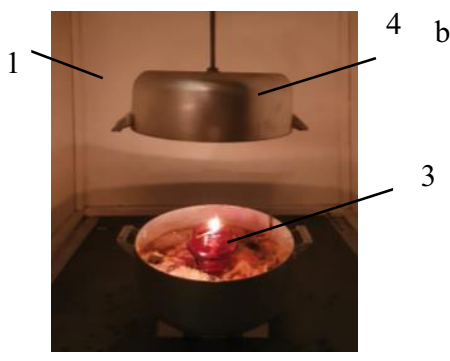

b)

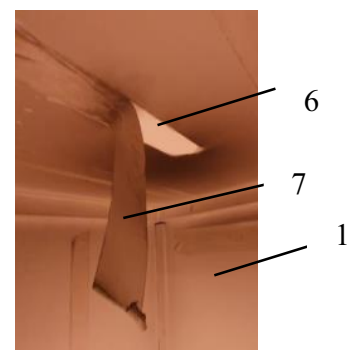

c)

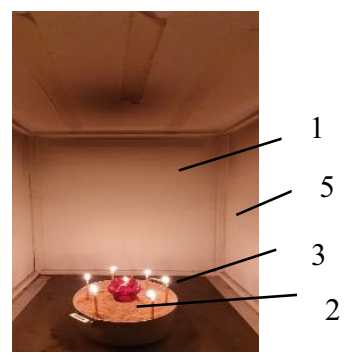

Fig. 3. The scheme of the experimental stand for studying the process of soot and soot emission on the surfaces of the walls and the decoration of the room: 1 - room; 2 - candlesticks; 3 - candle; 4 - a shelter for catching soot and soot; 5 - room wall; 6 - sticker of white paper on the surface of the ceiling up to burning candles; 7 - soot and soot; a - scheme of the shelter above the candlestick for trapping soot and soot; $\mathrm{b}$ - removing a part of the smoked paper from the ceiling surface; $\mathrm{c}$ - the state of the surface of the room at the beginning of the burning of candles.

Inside the room - 1 there is an imitation design of a candlestick -2 with burning candles 3 and a shelter - 4 for trapping soot and soot. The walls of the premises -5 are pasted over with white paper -6 . Within one month, when more than 4 thousand candles were burned, the walls and ceiling were covered with soot and soot -7 . Such processes also occur in the halls of worship when candles are burned, which negatively affects the decoration and decoration of the premises Orthodox churches, cathedrals and temples.

Regular repairs, refurbishment and restoration work require significant costs. To combat these hazards, most Orthodox churches, cathedrals and temples use energy-intensive ventilation and air conditioning systems in order to save money in combination with natural ventilation. To combat the harmful emissions from burning candles in the Church of the Nativity of the Most Holy Theotokos in Samara and in the Church of the Life-Giving Trinity in Astrakhan, a shelter was mounted above the candlesticks (Fig. 4, 5), which does not meet design requirements and does not ensure proper collection and soot from the hall of worship. There are other examples of shelters that do not have theoretical and experimental justification.

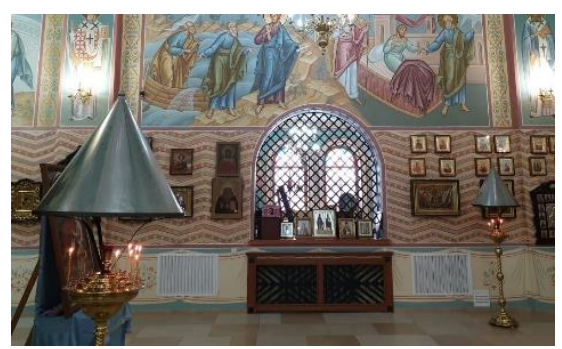

Fig. 4. Shelter on a candlestick in the Church of the Life-Giving Trinity in Astrakhan.

Despite the significant costs, the problem of creating an internal microclimate in the hall of worship of Orthodox churches, temples and cathedrals remains relevant and requires new approaches in order to catch and remove harmfulness when burning candles in the hall of worship. The authors propose an innovative system of the type of local exhaust mechanical ventilation for trapping and removing harmful substances directly in the places of their formation when burning candles in the worship hall of Orthodox churches, temples and cathedrals. At the same time, it is proposed to use traditional exhaust hoods for trapping and removing hazards (Fig. 5).

For technical solutions of local exhaust ventilation, well-known (Fig. 5 a, b, c) and proposed by the authors of the umbrella designs (Fig. $5 \mathrm{~d}$, e) are proposed. 

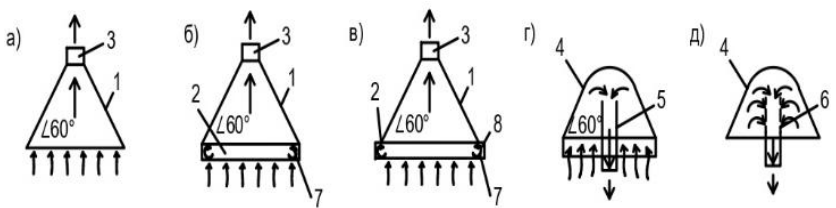

Fig. 5. Types of exhaust hoods above the table top of the lamps for removing the combustion products of candles: a - a simple umbrella; $b$ - umbrella with a canopy; $c$ - an umbrella with a pocket; $\Gamma$ - umbrella with overturned air removal; d - effective umbrella with overturned air removal; 1 - conical part; 2 skirt; 3 - exhaust air duct; 4 - conical part with rounding of the top of the umbrella; 5 - exhaust pipe; 6 - chimney perforated under the umbrella.

A preliminary analysis of the operation of the exhaust hood in natural conditions showed that its configuration, dimensions and height are set above the candlestick depend on a number of factors: the thermal power of the convective flow during the combustion of candles; the volume of air in the convective flow; the speed and temperature of the air in the vicinity of the hoods in the convective flow; the presence of external air movement in the hall of worship. Determination of the values of temperature and air velocity in the convective flow, necessary for the development of local exhaust ventilation, an experimental setup was created, shown in Fig 6 [6-8].

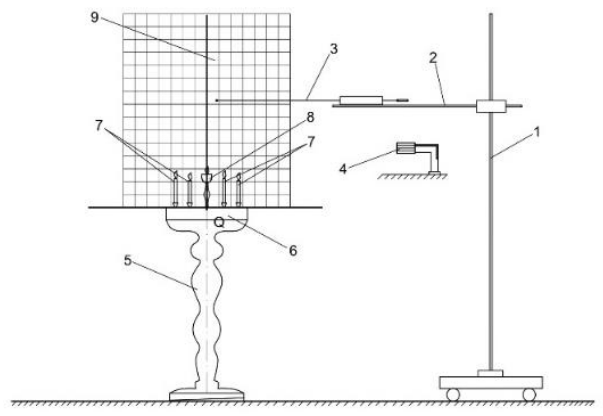

Fig. 6. Diagram of the experimental setup for studying the temperature and velocity fields of the convective flow during the combustion of candles: 1 - coordinator; 2 - holder of the coordinator; 3 hot-wire anemometer sensor; 4 - thermal imager; 5 - candlestick stand; 6 - candlestick tabletop; 7 candles; 8 - icon lamp; 9 - conditional coordinate grid.

Experimental studies of the parameters of the convective temperature flow $\mathrm{t} \mathrm{oC}$, air velocity $\mathrm{Vv}, \mathrm{m} / \mathrm{s}$, air flow rate $\mathrm{L} \mathrm{m} 3 / \mathrm{h}$, formed during the combustion of candles, were carried out in accordance with GOST 12.3.018-79 «Occupational safety standards system. Ventilation systems. Aerodynamic Test Methods». As a means of measuring the temperature and air velocity in the convective flow and at the periphery, a thermoanemometer of the TKAPKM type (60) was used, a combined device. A Testo-882-4 infrared thermal imager was used to determine the boundary of the convective flow, the temperature inside and on the flow axis.

The research was carried out in the worship hall of the Church of the Holy Apostles Peter and Paul in Penza using working candlesticks and natural paraffin candles, as well as a burning oil lamp [9-11].

In the course of experimental research, it was found that the convective air flow from an open flame during the combustion of candles placed on a candlestick tabletop differs significantly from traditional ones. (Fig. 7). 
a)

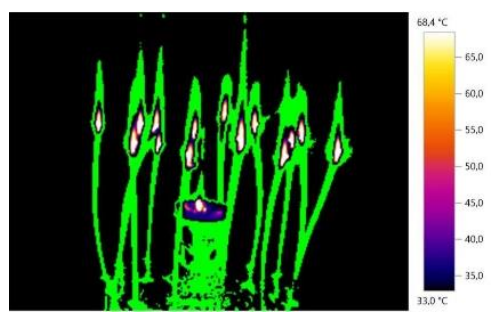

b)

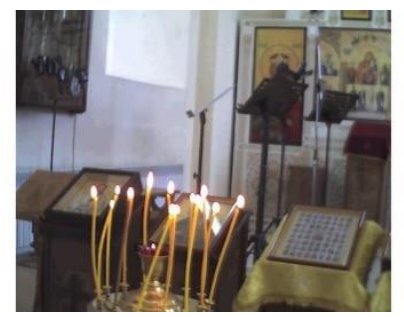

Fig. 7. Thermal image of an air cylindrical convective flow from burning candles: a - shape and temperature of air in the convective flow; $b$ - candlestick with burning candles.

Analysis of the data shown in Fig. 8 allows us to conclude that all candles installed around the perimeter in a certain one or several rows at a distance of 3-5 cm from each other (Fig. 7, b) and each individual candle forms its own individual convective air flow (Fig. 8, a). In the considered case, the total convective air flow consists of a multitude of individual convective jets that do not merge into a single flow (Fig. 7, a). The air temperature on the outside of the cylindrical convective flow varied from $33{ }^{\circ} \mathrm{C}$ in the upper part of the flow in the jet expansion zone to $68.4^{\circ} \mathrm{C}$ in the candle burning zone. The air temperature value must be taken into account when choosing the distance between the top of the candle flame and the lower edge of the hood. At a high temperature of the air flow, it is more efficient to capture and remove the harmfulness released during candle burning, in this case it can be 50-60 cm. On the axis of the cylindrical convective flow, where there are no candles, the air temperature is much lower than in the peripheral area with burning candles and varies from 25.3 to 33.2 - C. Candlesticks are used with the placement of candles over the entire area of the candlestick tabletop (Fig. 8, b). With this arrangement of candles, the convective flow consists of separate convective flows from each specific candle over the entire area of the candlestick tabletop (Fig. 8, a) [12-15].

a)

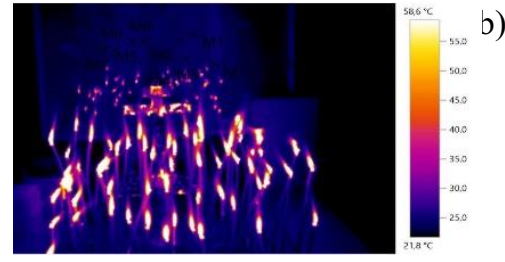

b)

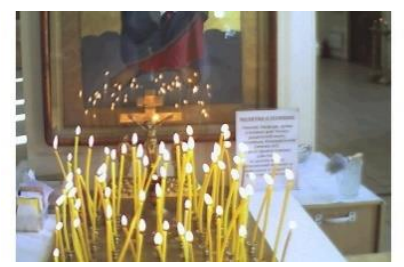

Fig. 8. Thermal image of a continuous convective air flow from burning candles: a - shape and temperature of the air in the convective flow; $\mathrm{b}$ - candlestick with burning candles.

In this case, the convective air flow, like the one discussed above, consists of separate convective flows from each individual candle (Fig. 8, a). The air temperature on the axis of the convective flow varies from $58.6 \mathrm{C}$ in the candle burning zone to $21.8{ }^{\circ} \mathrm{C}$ in the upper part of the flow in the expansion zone (Fig. 8, a). Taking into account the values of the air temperature in the convective flow and the convenience when setting candles by the parishioners, the distance from the top of the candle burning to the bottom of the edge of the exhaust canopy can be applied 50-60 cm. design and installation dimensions of the exhaust hood in the local exhaust ventilation system. Further research was carried out in natural conditions in the worship hall of the Church of the Holy Apostles Peter and Paul in Penza. On the experimental stand (Fig. 6), using a hot-wire anemometer, the values of the air temperature in the convective flow were measured above a separately burning candle located 
on the table top of the candlestick. The obtained experimental data are shown in the form of a graph in Fig. 9 [16-17].

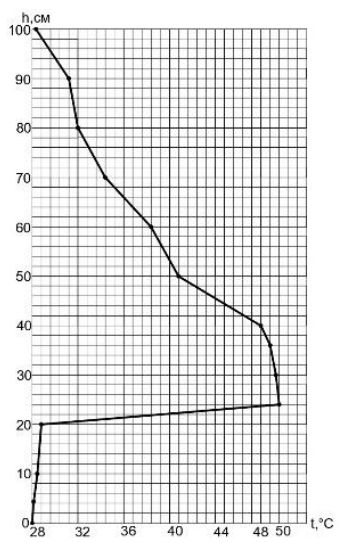

Fig. 9. The graph of the change in air temperature $t^{\circ} \mathrm{C}$ along the height $\mathrm{h}, \mathrm{cm}$ of the convective flow above a separately burning candle on a candlestick.

From the analysis of the graph of the change in the air temperature $t^{\circ} \mathrm{C}$ along the vertical $\mathrm{h}, \mathrm{cm}$ in the convective flow, we can conclude that the temperature changes slightly from 28 to $28.9^{\circ} \mathrm{C}$ along the height of the candle from 0 to $20 \mathrm{~cm}$ and practically corresponds to the ambient temperature. A sharp increase in air temperature in the stream is observed above the burning candle up to $50.1{ }^{\circ} \mathrm{C}$ and gradually decreases at a height of $60 \mathrm{~cm}$ to $39.2^{\circ} \mathrm{C}$ and at an altitude of $100 \mathrm{~cm}$ the air temperature in the stream corresponds to the ambient temperature in the church building.

At a height of up to $60 \mathrm{~cm}$, the convective flow remains stable due to the presence of a high temperature. This allows you to maximally capture the harmfulness with the help of an exhaust umbrella installed above the candlestick at a height of $60 \mathrm{~cm}$. The next stage of the experimental research was measuring the air temperature $\mathrm{t}^{\circ} \mathrm{C}$ along the height $\mathrm{h}, \mathrm{cm}$ along the axis of the cylindrical convective flow above the burning candles on the candlestick. The measurement results are shown in Fig 10.

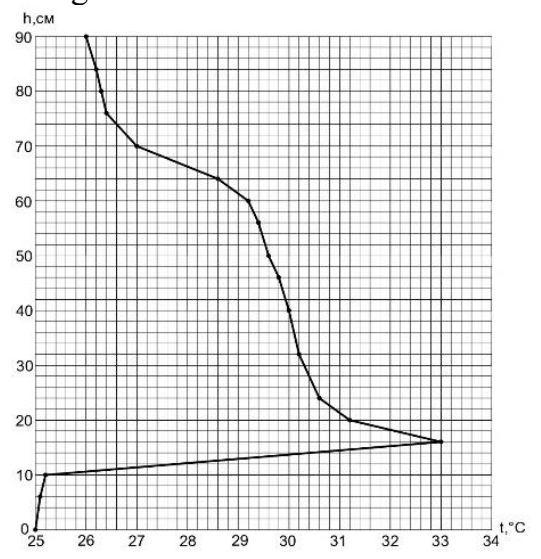

Fig.10. Graph of the change in air temperature ${ }^{\circ} \mathrm{C}$ along the height $\mathrm{h}, \mathrm{cm}$ on the axis of the cylindrical convective flow above the burning candles on the candlestick. 
It was found that the air temperature on the axis of the ascending convective flow is slightly lower than above the candles and varies from $25^{\circ} \mathrm{C}$ from the beginning of the flow to $25.2{ }^{\circ} \mathrm{C}$ vertically at a level of $20 \mathrm{~cm}$. The air temperature at the level of $30 \mathrm{~cm}$ reaches $33.1^{\circ} \mathrm{C}$. Then the temperature begins to decrease - at the level of $40 \mathrm{~cm}$ to $31.2^{\circ} \mathrm{C}$ and to $30.6^{\circ} \mathrm{C}$ at a height of $60 \mathrm{~cm}$ and up to $30.0^{\circ} \mathrm{C}$ at around $80 \mathrm{~cm}$ from the top of the candlestick tabletop. Further along the height, the temperature flows approach the state of the environment in the room. In the case under consideration, at a height of 0 to $70 \mathrm{~cm}$, the convective flow is most stable, which is very important for the efficiency of the exhaust hood. Low air temperatures on the axis of the cylindrical convective flow are explained by the absence of burning candles inside the flow. In order to achieve high efficiency of the exhaust hood and determine the height of the installation above the candlesticks, studies of changes in the convective flow velocity $\mathrm{V}, \mathrm{m} / \mathrm{s}$ in the area of air temperature measurement were carried out (Fig. 10, 11). The obtained results of speed studies were carried out using a hotwire anemometer and are shown in Fig. 11.

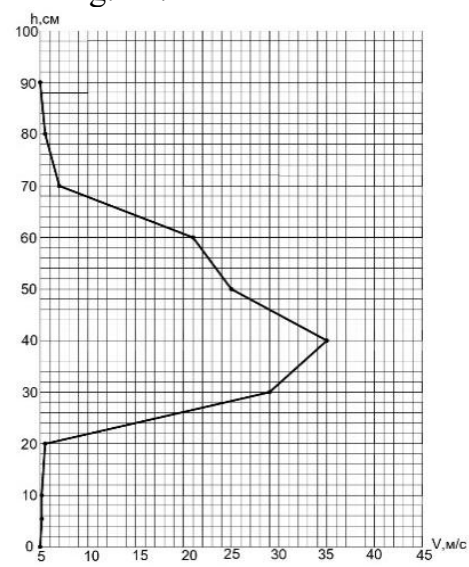

Fig. 11. The graph of the change in air velocity V, $\mathrm{m} / \mathrm{s}$ along the height $\mathrm{h}, \mathrm{cm}$ of the convective flow above a separately burning candle on a candlestick.

From the analysis of the data obtained, it follows that the air speed near the candle at a height of 0 to $20 \mathrm{~cm}$ varies slightly from 0.6 to $0.7 \mathrm{~m} / \mathrm{s}$, which corresponds to the mobility of air in the environment near the candlestick. A sharp increase in speed is observed in the jet above the candle flame at a height of $30 \mathrm{~cm}$ and corresponds to $28 \mathrm{~m} / \mathrm{s}$ and reaches a maximum in the jet of $36 \mathrm{~m} / \mathrm{s}$ at around $40 \mathrm{~cm}$. Further, as you move away from the burning candle, the air velocity in the jet decreases to $23.8 \mathrm{~m} / \mathrm{s}$ at a distance of $50 \mathrm{~cm}$ and $19.4 \mathrm{~m} / \mathrm{s}$ at a height of $60 \mathrm{~cm}$ and $6.6 \mathrm{~m} / \mathrm{s}$ at $70 \mathrm{~cm}$. The obtained results of the study of the temperature and air velocity (Fig. 10, 11, 12) allow us to determine the zone of stable convective flow within $\mathrm{h}$ $50-60 \mathrm{~cm}$. Therefore, the exhaust hood must be installed in the zone of stable convective flow, indicated in the range from the table top of the candlestick to the lower edge exhaust hood. These conditions will ensure effective trapping and removal of harmful substances when burning candles from the area of worship outside the premises. The proposed exhaust hoods are installed in the local mechanical exhaust ventilation system (Fig.12).

In the specified ventilation system, it is recommended to install all candlesticks in one line along the outer wall of the worship hall at a distance convenient and safe for parishioners. Hazards released during the combustion of candles- 3 and lamps- 4 from umbrellas- 5 enter the exhaust system of air duct- 8 and then, using fan- 6 , are removed into the atmosphere through air duct-7.

At $90 \mathrm{~cm}$, the air velocity in the jet corresponds to $0.2 \mathrm{~m} / \mathrm{s}$, as in the room. It is important to note that the air velocity at the edge of the jet above the flame is much lower and amounts 
to $1 \mathrm{~m} / \mathrm{s}$. On the basis of the studies carried out, the authors propose the following model of the structure of a convective air flow as a result of heat release from open burning of candles on a candlestick Fig. 12. In this case, the revealed values of temperature and air mobility in the convective flow, obtained using a thermal imager and a hot-wire anemometer, were used. When forming the model, the methods of Shepelev I.A.
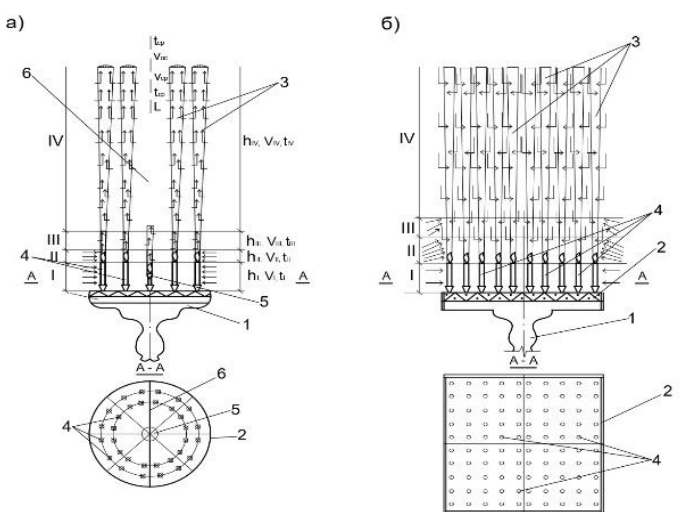

Fig.12. Scheme of the structure of the total convective jet above the flame of burning candles above the candlestick table top: a-cylindrical; b - rectangular. I - passive section of adjacent air leakage; II - active area of adjacent air leakage; III - acceleration section; IV - section of expansion of each candle due to the leakage of adjacent air; hI, hII, hIII, hiv — height of the corresponding zone, cm; VI, VII, VIII, Viv - air speed in the corresponding section, $\mathrm{m}$ / s; tI, tII, tIII, tiv - air temperature in the corresponding section, oC; tos, Vos - respectively, temperature and velocity on the axis of the total convective jet; tav, Vav - respectively, the average temperature and velocity on the axis of the total convective jet; $\mathrm{L}$ is the air flow rate in the total convective jet $\mathrm{m} 3 / \mathrm{h} ; 1$ - candlestick; 2 - table top; 3-convective flow from a separate candle; 4 - candle; 5 - icon lamp; 6 - the hollow part of the cylindrical convective flow.

The obtained results of the study of the temperature and air velocity (Fig. 10, 11, 12) allow us to determine the zone of stable convective flow within h $50-60 \mathrm{~cm}$. Therefore, the exhaust hood must be installed in the zone of stable convective flow, indicated in the range from the table top of the candlestick to the lower edge exhaust hood. These conditions will ensure effective trapping and removal of harmful substances when burning candles from the area of worship outside the premises. The proposed exhaust hoods are installed in the local mechanical exhaust ventilation system (Fig.13)

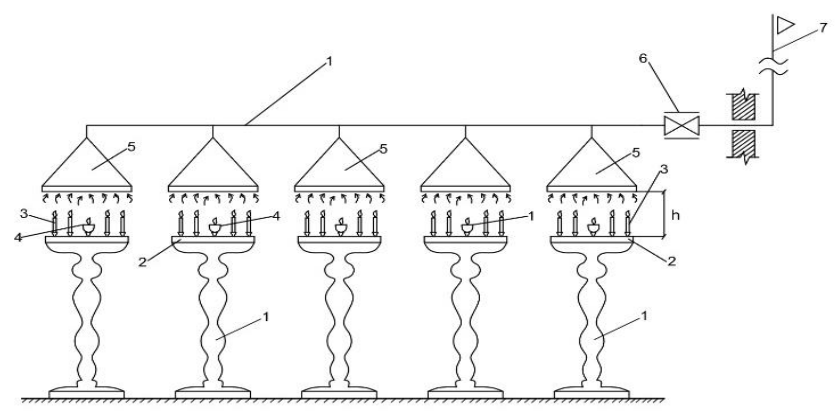

Fig. 13. The proposed scheme of the local mechanical exhaust ventilation system: 1 - candlestick; 2table top; 3 - candle; 4 - icon lamp; 5 - exhaust hood; 6 - fan; 7 - removal of polluted air; 8 - air duct system; $h$ is the distance from the table top to the lower edge of the umbrella. 
The proposed local exhaust ventilation system will provide comfortable conditions for parishioners and will preserve the interior decoration of the worship hall of the church, temple and cathedral. To effectively trap polluted heated air with an exhaust hood, it is important to know the regularities of the convective flow. In this case, the heat flow has four sections I, II, III and IV (Fig. 12), which differ from each other by changing the air flow rate $\mathrm{L} \mathrm{m}^{3} / \mathrm{h}$, temperature $\mathrm{t}^{\circ} \mathrm{C}$, velocity $\mathrm{V} \mathrm{m} / \mathrm{s}$ and the nature of the flow. In passive section $\mathrm{I}$, there is a slight leakage of ambient air $\mathrm{L} \mathrm{m}^{3} / \mathrm{h}$ to the source of candle combustion at low $\mathrm{V} \mathrm{m} / \mathrm{s}$ and $t{ }^{\circ} \mathrm{C}$. Active section II is characterized by intensive inflow of adjacent air to the combustion site and acceleration of the adjacent air to the combustion site and acceleration of the convective flow mass movement, which leads to the formation of a narrow part of the flow cross section. The acceleration of the convective flow occurs in section III, then in section IV the convective flow begins to gradually expand due to the leakage of adjacent air and then dies out and dissolves in the environment. The revealed features and sections of the convective flow are necessary to determine the size and volume of the exhaust hood, the location of its installation, the distance from the place of burning candles to the lower edge of the hood. It has been established that the total convective flow consists of separate individual convective flows (Fig. 8.9) of air, formed from each separate burning candle, which in section IV do not interconnect, but when decaying are mixed with the environment. These judgments are justified by the value of $\mathrm{t}^{\circ} \mathrm{C}$ and $\mathrm{V} \mathrm{m} / \mathrm{s}$, shown in the graph in Fig. 9, 10, 11 and Fig. 12. It is proposed to install the hoods over the burning candles. The space between the candles and the lower edge of the umbrella covers areas I, II, and III at a distance of 50 to $60 \mathrm{~cm}$ and provides free flow of adjacent air. This contributes to the complete removal of combustion products from candles: heat, soot, steam, soot and carbon dioxide. The conducted research and the results obtained make it possible to develop a methodology for calculating the local exhaust ventilation system and the dimensions of the exhaust hood for trapping and removing the harmfulness generated by burning candles on candlesticks and ensuring the preservation of historical and artistic values in the hall of worship, as well as creating comfortable conditions for parishioners and staff Orthodox churches, cathedrals and temples.

\section{References}

1. Dmitrieva L.S., Kuzmina L.V., Moshkarnev L.M. Planning an experiment in ventilation and air conditioning. [Planiruyem eksperiment po ventilyatsii i konditsionirovaniyu]. Irkutsk .: Irkutsk University, 1987.210p. (rus)

2. Kassandrova ON, Lebedev VV. Processing of observation results. [Obrabotka rezul'tatov nablyudeniya]. Moscow: Nauka, 1970.210p. (rus)

3. Uspenskaya G.V. Mathematical statistics in ventilation technology. [Matematicheskaya statistika v ventilyatsionnoy tekhnike]. M .: Stroyizdat, 1980.108 p. (rus)

4. Shepelev I.A. Indoor air flow aerodynamics. [Aerodinamika vozdushnogo potoka v pomeshchenii]. M .: Stroyizdat, 1978.178p. (rus)

5. Kochev A.G. Microclimate of Orthodox churches. [Mikroklimat pravoslavnykh khramov]. NNGASU. 2004.449p. (rus)

6. Annunciation. How can temples breathe? [Kak khramy mogut dyshat']. [Electronic resource]. URL: https://blagovest.ru/blog/chem-dyshat-khramy. (date of treatment 12/02/2020). (rus)

7. Eremkin A.I., Ponomareva I.K., Bagdasaryan A.G. Analysis and methods of providing a microclimate in Orthodox cathedrals and temples. [Analiz i metody obespecheniya mikroklimata v pravoslavnykh soborakh i khramakh]. Education and Science in the Modern World. Innovation. 2020. No. 4. P. 151-158. (rus) 
8. Eremkin A.I., Ponomareva I.K., Petrova K.A., Bagdasaryan A.G. Ways to improve the quality of the microclimate in the worship hall of the Spassky Cathedral in Penza. [Sposoby uluchsheniya kachestva mikroklimata v molel'nom zale Spasskogo sobora v Penze]. Regional architecture and construction. 2020. No. 4. P. 125-136. (rus)

9. Eremkin A.I., Ponomareva I.K., Bagdasaryan A.G. The influence of the sanitary and hygienic state of the microclimate in the halls of worship of Orthodox cathedrals on the physiological state of parishioners. [Vliyaniye sanitarno-gigiyenicheskogo sostoyaniya mikroklimata $\mathrm{v}$ molel'nykh zalakh pravoslavnykh soborov na fiziologicheskoye sostoyaniye prikhozhan]. Education and Science in the Modern World. Innovation. 2020. No. 6. P. 151-155. (rus)

10. Kochev A.G. Microclimate conditioning systems in Orthodox churches. [Sistemy konditsionirovaniya mikroklimata $\mathrm{v}$ pravoslavnykh khramakh]. M $\therefore$ AVOK - Press. 2009. 230 p. (rus)

11. Konovalov, V.I. Technical thermodynamics [Tekhnicheskaya termodinamika]. Ivanovo: Ivanovo State Power Engineering University named after V.I. Lenin. 2005.620 p

12. Orlov M.E. Theoretical foundations of heat engineering. Heat and mass transfer [Teoreticheskiye osnovy teplotekhniki. Teplomassoobmen]. Ulyanovsk: UlGTU. 2013.204 p.

13. Bukhmirov V.V. Non-stationary thermal conductivity [Nestatsionarnaya teploprovodnost]. Ivanovo: Ivanovo State Power Engineering University named after V.I. Lenin.2013.360 p.

14. Miram A.O. Technical thermodynamics. Heat and mass transfer [Tekhnicheskaya termodinamika]. M.: ASV. 2011.352 p.

15. Kudinov A.A. Heat and mass transfer [Teplomassoobmen]. M.: INFRA-M. 2012.374 p.

16. Bearzi V. Luoghi di culto. Impianti Radianti o Misti. RCI. Febraio. 2003.

17. Rahimian A.Yoram Eilon. New York's Hearst Tower. A Restoration, an Adaptive Reuse and a Modern Steel Tower Rolled Into One. Structure magazine 2006. No 02, - P. 25-29. 